\title{
Formoterol Fumarate Oral
}

\author{
National Cancer Institute
}

\section{Source}

National Cancer Institute. Formoterol Fumarate Oral. NCI Thesaurus. Code C85467.

The orally bioavailable fumarate salt of formoterol, a long-acting, selective beta2adrenergic receptor agonist with bronchodilating and potential anti-cachexia and anabolic activities. In addition to formoterol's bronchodilating activity, formoterol exhibits anticachexia activity through the inhibition of the ATP-ubiquitin-dependent proteolytic system, which may result in a decrease in protein degradation and muscle cell apoptosis. In addition, formoterol may also increase insulin-like growth factor (IGF) signaling, resulting in an increase in protein synthesis. This agent may also inhibit the calciumdependent calpain system, resulting in the inhibition of muscle wasting. 